\title{
A hemodialysis patient with Mycobacterium avium complex pericarditis in which remarkable presepsin elevation was not accompanied by procalcitonin elevation
}

\author{
Jun Shiota
}

\begin{abstract}
Background: The application of presepsin for diagnosing infections in hemodialysis (HD) patients has not been confirmed yet. In addition, whether presepsin can detect atypical mycobacterial infection or not remains unknown.

Case presentation: We describe the case of a 66-year-old male HD patient with pericardial tamponade. Mycobacterium avium complex (MAC) was identified from a culture of pericardial effusion. The patient showed a clinical improvement after approximately 1 year without the administration of antibiotics. Remarkably, high plasma presepsin values were observed without an increase in serum procalcitonin values. The patient's presepsin values decreased after the treatment of MAC induced pericarditis.
\end{abstract}

Conclusions: We found a HD patient with mycobacterium avium complex pericarditis with remarkable presepsin elevation unaccompanied by PCT elevation.

Keywords: Mycobacterium avium complex, Pericarditis, Presepsin, Procalcitonin

\section{Background}

Although Mycobacterium avium complex (MAC) bacilli show low virulence, even immunocompetent individuals can be infected, suggesting some need for caution in hemodialysis (HD) patients. Because MAC easily acquires antibiotic resistance, antibiotics are not necessarily used, and spontaneous remission can be expected [1, 2]. In case of pulmonary MAC infection, the disease activity can be monitored by sputum culture; however, a biomarker is desired for monitoring MAC infection, the pathogen of which cannot easily be detected. Therefore, a biomarker that reflects the activity of the immune response in real-time at the focus of MAC infection might be useful for confirming the amelioration of MAC infection. Presepsin (P-SEP) is an N-terminal fragment of CD14 that is expressed on the cell surface of macrophages/monocytes and its concentration in the blood increases in association with phagocytosis by macrophages/monocytes [3, 4]. In contrast, procalcitonin (PCT) is released from various cells other than macrophages/monocytes during stimulation by proinflammatory cytokines [5]. In the present case report, we describe the case of an HD patient, who developed cardiac tamponade and who showed spontaneous improvement after pericardial drainage without antibiotics. The patient revealed remarkable high plasma P-SEP levels unaccompanied by increased serum PCT levels during the clinical course of MAC pericarditis.

Correspondence: junshio@jcom.home.ne.jp

Department of Internal Medicine, Tsunashima Kidney Clinic, 1-10-4,

Tsunashima-Higashi, Kohoku-ku, Yokohama 223-0052, Japan

C C The Author(s). 2020 Open Access This article is licensed under a Creative Commons Attribution 4.0 International License, which permits use, sharing, adaptation, distribution and reproduction in any medium or format, as long as you give appropriate credit to the original author(s) and the source, provide a link to the Creative Commons licence, and indicate if changes were made. The images or other third party material in this article are included in the article's Creative Commons licence, unless indicated otherwise in a credit line to the material. If material is not included in the article's Creative Commons licence and your intended use is not permitted by statutory regulation or exceeds the permitted use, you will need to obtain permission directly from the copyright holder. To view a copy of this licence, visit http://creativecommons.org/licenses/by/4.0/ The Creative Commons Public Domain Dedication waiver (http://creativecommons.org/publicdomain/zero/1.0/) applies to the data made available in this article, unless otherwise stated in a credit line to the data. 


\section{Case presentation}

We describe the case of a 66-year-old male HD patient with diabetes mellitus. He complained cough and shortness of breath from October 2018 and was hospitalized due to cardiac tamponade from December 1, 2018. Nine hundred milliliter of pericardial effusion was removed by pericardial puncture. Laboratory data showed white blood cell count of $9166 / \mu \mathrm{L}$, high-sensitivity C-reactive protein (hsCRP) $13.50 \mathrm{mg} / \mathrm{dL}, \mathrm{LD} 239 \mathrm{IU} / \mathrm{L}, \mathrm{TP} 7.4 \mathrm{~g} / \mathrm{dL}$, and Alb $3.0 \mathrm{~g} / \mathrm{dL}$. Human immunodeficiency virus (HIV) serology was negative. The bloody pericardial effusion was exudative (LD, $866 \mathrm{IU} / \mathrm{L} ; \mathrm{TP}, 5.7 \mathrm{~g} / \mathrm{dL}$; Alb, $2.5 \mathrm{~g} /$ $\mathrm{dL}$ ), with a white blood cell count of $4320 / \mu \mathrm{L}$ (lymphocyte dominant 53.5\%). Cytological examination revealed no malignancy. MAC was identified in a pericardial effusion culture, but not in a blood culture (Table 1). Physical examination revealed no lymphadenopathy, skin lesion, or joint swelling. Computed tomography revealed no lung abnormality. On the other hand, three-vessel disease (no. $1100 \%$, no. $575 \%$, no. $690 \%$, no. 1190 $\%)$ was diagnosed based on the coronary angiography findings, and coronary artery bypass grafting was performed on December 26, 2018. Intraoperative findings demonstrated severe adhesion of the pericardium and hypertrophy of the epicardium. The pathological examination of the pericardium revealed severe fibrous thickening without granulomas. The postoperative clinical course was uneventful. Considering the emergence of antibiotic-resistant bacteria and the possibility of natural healing, no antibiotics were administered after the

Table 1 Laboratory findings

\begin{tabular}{llll}
\hline Blood & \multicolumn{3}{l}{ Pericardial effusion } \\
\hline Complete blood count & \multicolumn{2}{c}{ Laboratory examination } \\
WBC & $9160 / \mu \mathrm{L}$ & $\mathrm{LD}$ & $866 \mathrm{IU} / \mathrm{L}$ \\
$\mathrm{RBC}$ & $318 \times 10^{4} / \mu \mathrm{L}$ & $\mathrm{TP}$ & $5.7 \mathrm{~g} / \mathrm{dL}$ \\
$\mathrm{Hb}$ & $9.3 \mathrm{~g} / \mathrm{dL}$ & $\mathrm{Alb}$ & $2.5 \mathrm{~g} / \mathrm{dL}$ \\
$\mathrm{Ht}$ & $29.7 \%$ & WBC & $4320 / \mu \mathrm{L}$ \\
$\mathrm{Plt}$ & $19.5 \times 10^{4} / \mu \mathrm{L}$ & & Lymphocytes $53.5 \%$ \\
Immunology & & Mycobacterium culture \\
hsCRP & $13.50 \mathrm{mg} / \mathrm{dL}$ & Mycobacterium avium complex \\
HBs-Ag & $(-)$ & Cytology \\
HCV-Ab & $(-)$ & No malignancy \\
RPR (Syphilis) & $(-)$ & \\
HIV-Ab & $(-)$ & \\
Chemistry & & \\
LD & $239 \mathrm{IU} / \mathrm{L}$ & \\
TP & $7.4 \mathrm{~g} / \mathrm{dL}$ & \\
Alb & $3.0 \mathrm{~g} / \mathrm{dL}$ & \\
Mycobacterium culture & \\
Negative & & \\
\hline
\end{tabular}

diagnosis of MAC pericarditis. On the postoperative day 27 (2019/1), the pre-HD serum PCT value (CLEIA, Lumipulse Presto Brahmus PCT, FUJIREBIO, Tokyo, Japan) was $0.35 \mathrm{ng} / \mathrm{mL}$, which is approximately 7 times the reference value in healthy individuals ( 97.5 percentile: $0.05 \mathrm{ng} / \mathrm{mL}$ ), while the pre-HD plasma P-SEP value (CLEIA, STACIA CLEIA Presepsin, LSI Medience, Tokyo, Japan) was $14100 \mathrm{pg} / \mathrm{mL}$, which is approximately 50 times the reference value in healthy individuals $(95$ percentile $314 \mathrm{pg} / \mathrm{mL}$ ). From January to September 2019, the patient's plasma P-SEP values remained very high without an increase in PCT. Thereafter, the plasma PSEP values decreased, and at the same time, his serum MAC antibody titer (EIA, Capilia MAC Ab ELISA, TAUNS Laboratories, Shizuoka, Japan) was $0.5 \mathrm{U} / \mathrm{mL}$ (negative) (Fig. 1). Although the pre-HD serum hsCRP increased for 1 month after operation with the peak value of $15.99 \mathrm{mg} / \mathrm{dL}$, thereafter, it decreased bellow $1.00 \mathrm{mg} / \mathrm{dL}$ from March 2019 (Fig. 1). Small amount of pericardial effusion was found by echocardiography at June 2019. In addition, activation of Epstein-Barr virus (EBV) or cytomegalovirus (CMV) was considered unlikely because a laboratory examination revealed the following results: EBV-VCA-IgG [FA], X20; EBV-VCAIgM [FA], X10 >; EBV-EADR-IgG [FA], X10 >; EBVEBNA [FA], X40; EBV nucleic acid quantification (white blood cell), not detected; and CMV pp65 antigen C10, C11, negative. A bone marrow examination showed no evidence of hemophagocytic syndrome.

\section{Discussion and conclusions}

MAC pericarditis has been reported mainly in patients with HIV infection [6,7], but immunocompetent subject can also be infected $[8,9]$. To the best of our knowledge, this is the first case report of MAC pericarditis in a HD patient.

In the present case of MAC pericarditis, the remarkable increase in plasma P-SEP may reflect the phagocytosis and digestion of MAC by activated macrophages/ monocytes. No granulomas were found in the epicardium, in contrast to the severe adhesion of the pericardium, suggesting that MAC infection was only located within the pericardium. Thus, it was inferred that the removal of pericardial effusion powerfully supported the MAC infection control by the patient's immune response via the reduction of the bacterial burden. Kitada et al. [10] demonstrated a patient of 61-year-old female patient with pulmonary MAC disease undergone lung lobectomy whose serum MAC antibody titer decreased after operation. Although MAC antibody titers are determined not only by the disease activity but also by an individual's immune response, MAC antibody titers could be a useful indicator of the disease activity in some individual patient [11]. In the present case of MAC 


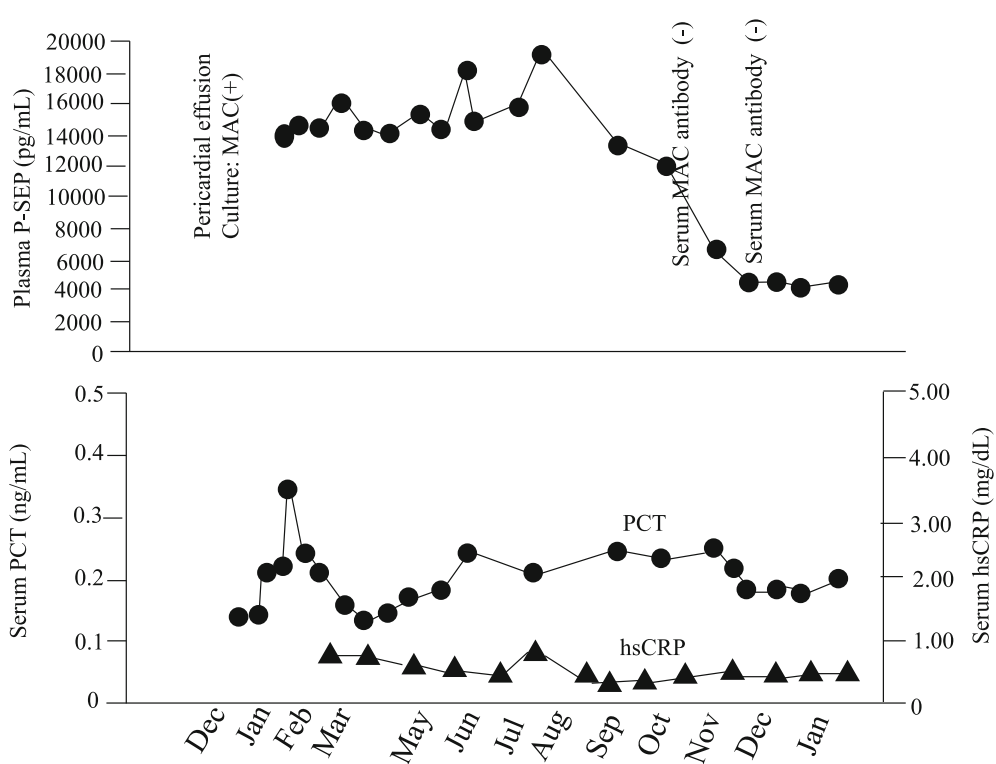

Fig. 1 The clinical course. The plasma presepsin (P-SEP), serum procalcitonin (PCT), and high-sensitivity C-reactive protein (hsCRP) levels after the removal of pericardial effusion containing Mycobacterium avium complex (MAC) are indicated. Although the serum PCT levels did not change throughout the clinical course, the plasma P-SEP levels remained very high until the patient's serum MAC antibody titer was negative. After the perioperative period with a peak level of $15.99 \mathrm{mg} / \mathrm{dL}$, hsCRP remained below $1.00 \mathrm{mg} / \mathrm{dL}$

pericarditis, MAC antibody-negative might at least be consistent with decreased immune response, because the decreased plasma P-SEP levels probably reflect suppressed phagocytosis and digestion against MAC by macrophages/monocytes.

Because the serum PCT and plasma P-SEP levels increase with the deterioration of the renal function [12], reference values have not been established for HD patients without infection. The previously reported preHD PCT levels in patients without infection are approximately $0.17-0.79 \mathrm{ng} / \mathrm{mL}$ (median) and $0.20-0.50 \mathrm{ng} / \mathrm{mL}$ (mean) [13-18]; thus, the PCT levels did not increase at all in the present case (Table 2). On the other hand, the previously reported pre-HD P-SEP levels in patients without infection are approximately $1434-1510 \mathrm{pg} / \mathrm{mL}$ (median) and $1327 \mathrm{pg} / \mathrm{mL}$ (mean) [12, 19-22]; thus, the patient showed persistently high P-SEP levels from January to September 2019 (Table 2, Fig. 1). In contrast, the patient's serum MAC antibody titer was negative when the plasma P-SEP level was decreasing, suggesting that the increase in the P-SEP levels reflected the disease activity in this case of MAC infection.

The hypothesized mechanism by which the serum PCT levels were not increased while MAC pericarditis was controlled by the immune response is as follows. MAC infection of the pericardium is first incorporated into macrophages/monocytes; however, MAC has strong resistance against phagocytosis and digestion. Macrophages/monocytes therefore induce the production of interferon- $\gamma$ (IFN- $\gamma$ ) from NK cells or the type 1 helper $\mathrm{T}$ (Th 1) cells which were received antigen presentation via IL-12, which is secreted from macrophages/

Table 2 PCT and P-SEP values of present HD patient and previously reported HD patients without infection

\begin{tabular}{|c|c|c|c|c|c|c|c|}
\hline N & Assay & Serum $P C T, n g / m L$ & Ref. & N & Assay & Plasma P-SEP, pg/mL & Ref. \\
\hline 123 & ECLIA & median 0.23 & 13 & 17 & CLEIA & median (IQR) 1434 (1171-1891) & 19 \\
\hline 89 & ECLIA & $\begin{array}{l}\text { mean } \pm \text { SD } 0.23 \pm 0.25 \\
\text { median(range) } 0.17(9.05-1.73)\end{array}$ & 14 & 10 & CLEIA & median (IQR) 1305 (814-1858) & 20 \\
\hline 20 & ELFA & mean \pm SD $0.50 \pm 0.49$ & 15 & 20 & CLEIA & median (IQR) 1510 (1205-1810) & 21 \\
\hline 48 & ECLIA & median (5th-95th percentile) 0.17 (0.090-0.824) & 16 & 98 & CLEIA & mean \pm SD $1327 \pm 914$ & 22 \\
\hline 61 & ECLIA & mean \pm SD $0.20 \pm 0.14$ & 17 & 13 & CLEIA & median (IQR) 1160 (1070-1400) & 12 \\
\hline \multirow[t]{2}{*}{23} & IFA & median (95\% Cl) 0.79 (0.45-0.99) & 18 & & & & \\
\hline & CLEIA & $0.17-0.35$ & & & CLEIA & 19000-12100 (2019/1 2019/9) & \\
\hline
\end{tabular}

PCT procalcitonin, P-SEP presepsin, HD hemodialysis, MAC Mycobacterium avium complex, ECLIA electrochemiluminescence immunoassay, ELFA enzyme-linked fluorescent assay, IFA immunofluorescence assay, SD standard deviation, $C l$ confidence interval, IQR interquartile range

The data of the last line indicate the PCT and P-SEP values in the present case report. All other values pertain to cases involving HD patients without infection 
monocytes, resulting in the further reinforcement of the phagocytic activity of the macrophages/monocytes [23]. Although PCT is produced by various cells, including adipocytes, in response to stimulation with proinflammatory cytokines released from the focus of infection, the production of PCT is definitely suppressed by IFN- $\gamma$ [5]. Thus, the serum PCT levels do not increase in accordance with the process of phagocytosis and digestion. It appears that where culture specimens cannot be obtained, the disease activity of MAC infection may be monitored by the simultaneous measurement of the PCT and P-SEP levels.

This report has limitations. First, serum MAC antibody titter was not measured before pericardial drainage and operation which remove bacterial burden. Second, serum IFN- $\gamma$ levels were not measured in the present case report, but Burgess LJ et al. [24] demonstrated that the IFN- $\gamma$ levels of pericardial effusion can be a reliable indicator of tuberculous pericarditis. Third, more cases need to be accumulated for the utility of P-SEP in evaluating MAC pericarditis activity.

\section{Abbreviations}

MAC: Mycobacterium avium complex; HD: Hemodialysis; P-SEP: Presepsin; CD14: Cluster differentiation 14; PCT: Procalcitonin; hsCRP: High-sensitivity Creactive protein; LD: Lactate dehydrogenase; TP: Total protein; Alb: Albumin; CLEIA: Chemiluminescent enzyme immunoassay; ElA: Enzyme immunoassay; EBV: Epstein-Barr virus; CMV: Cytomegalovirus; IFN- $\gamma$ : Interferon- $\gamma$; NK cell: Natural killer cell; IL-12: Interleukin-12

\section{Acknowledgements}

The authors would like to thank Nippon Medical School Musashi Kosugi Hospital for making the diagnosis of MAC pericarditis.

\section{Authors' contributions}

JS acquired the clinical data and drafted the manuscript. The author read and approved the final manuscript.

\section{Funding}

The present case report was not supported by funding.

\section{Availability of data and materials}

All data analyzed during this study are included in this published article.

\section{Ethics approval and consent to participate}

The authors have no ethical conflicts to disclose. The present case report was approved by our institution's Institutional Review Board.

\section{Consent for publication}

Written informed consent was obtained from the patient.

\section{Competing interests}

The authors declare no conflict of interest in association with the present study.

Received: 15 January 2020 Accepted: 30 March 2020

Published online: 16 April 2020

\section{References}

1. Kobayashi K. Serodiagnosis of mycobacterium avium complex disease in humans: translational research from basic mycobacteriology to clinical medicine. Jpn J infect Dis. 2014;67:329-32.

2. Griffith DE, Aksamit T, Brown-Elliott BA, Catanzaro A, Daley C, Gordin F, et al. An official ATS/IDSA statement: diagnosis, treatment, and prevention of nontuberculous mycobacterial diseases. Am J Respir Crit Care Med. 2007:175: $367-416$.
3. Arai Y, Mizugishi K, Nonomura K, Naitoh K, Takaori-Kondo A, Yamashita K. Phagocytosis by human monocytes is required for the secretion of presepsin. J Infect Chemothr. 2015;21:564-9.

4. Naitoh K, Shirakawa K, Hirose J, Nakamura M, Takeuchi T, Hosaka Y, et al. The new sepsis marker, sCD14-ST (PRESEPSIN), induction mechanism in the rabbit sepsis models. Crit Care. 2010;14(Supple 2):19.

5. Linscheid P, Seboek D, Nylen ES, Langer I, Schlatter M, Becker KL, et al. In vitro and in vivo calcitonin I gene expression in parenchymal cells: a novel product of human adipose tissue. Endocrinology. 2003;144(12):5578-84.

6. Babu TM, Laguio M, Luque AE, Larppanichpoonphol P. Mycobacterium avium-complex pericarditis: a case of unmasking immune reconstitution inflammatory syndrome. Int J STD AIDS. 2014;25(2):148-51.

7. Viehman JA, Khalil D, Barhoma C, Hanna RM. Mycobacterium aviumintracellulare otomastoiditis in a young AIDS patient: case report and review of the literature. HIV AIDS. 2013;5:61-6.

8. Jolobe $\mathrm{OM}$. The association of mycobacterium avium complex infection and pericarditis in immnocompetent subjects. Eur J Intern Med. 2009;20(5):e129.

9. Marvisi M, Bassi E, Zanlari L, Civardi G. A case mycobacterium avium complex infection in an immunocompetent man presenting with pericarditis and an HRCT pattern of lymphangitis. Eur J Int Med. 2008;19(4):300-2.

10. Kitada S, Maekura R, Toyoshima N, Naka T, Fujiwara N, Kobayashi M, et al. Use of glycopeptidolipid core antigen for serodiagnosis of mycobacterium avium complex pulmonary disease in immunocompetent patients. Clin Diagn Lab Immunol. 2005;12(1):44-51.

11. Kitada S, Maekura R, Yoshimura K, Miki K, Miki M, Oshitani Y, et al. Levels of antibody against glycopeptidolipid core as a marker for monitoring treatment response in Mycobacterium avium complex pulmonary disease: a prospective cohort study. J Clin Microbil. 2017;55(3):884-92.

12. Nagata $T$, Yasuda $Y$, Ando M, Abe T, Katsuno T, Kato $S$, et al. Clinical impact of kidney function on presepsin levels. PLoS ONE. 2015;10(6):e0129159.

13. Kubo S, Iwasaki M, Horie M, Matsukane A, Hayashi T, Tanaka Y, et al. Biological variation of procalcitonin levels in hemodialysis patients. Clin Exp Nephrol. 2019:23:402-8.

14. Ichihara K, Tanaka T, Takahashi S, Matsukawa M, Yanase M, Kitamura H, et al. Serum procalcitonin level in chronic hemodialytic patients with no evidence of bacterial infection. Renal Replacement therapy. 2016;2:9.

15. Lee WS, Kang DW, Back JH, Kim HL, Chung JH, Shin BC. Cutoff value of serum procalcitonin as a diagnostic biomarker of infection in end-stage renal disease patients. Korean J Med. 2015;30(2):198-204.

16. Trimarchi H, Dicugno M, Muryan A, Lombi F, Iturbe L, Rana MS, et al. Procalcitonin and inflammation in chronic hemodialysis. Medicina. 2013:73(5):411-6.

17. Mori K, Noguchi M, Sumino Y, Sato F, Mimata H. Use of procalcitonin in patients on chronic hemodialysis: procalcitonin is not related with increased serum calcitonin. ISRN Urol. . https://doi.org/10.5402/2012/431859.

18. Lavin-Gomez BA, Palomar-Fontanet R, Gago-Fraile M, Quintanar-Lartundo JA, Gomez-Palomo E, Gonzalez-Lamuno D, et al. Inflammation markers, chronic kidney disease, and renal replacement therapy. Adv Perit Dial. 2011;27:33-7.

19. Kobayashi S, Amano H, Terawaki H, Kawaguchi Y, Yokoo T. Prediction of presepsin concentrations through commensurate decline in kidney function in the elderly. Clin Chim Acta. 2020;500:1-9.

20. Shiota J. Changes of early sepsis biomarker presepsin level during hemodialysis: influence of $\beta_{2}$-microglobulin clearance of dialysis membrane: a preliminary study. Kidney Dis. 2019;5(1):43-50.

21. Shiota J, Tagawa H, Ohura N, Kasahara H. Presepsin is a potent biomarker for diagnosing skin wound infection in hemodialysis patients compared to white blood cell count, high-sensitivity C-reactive protein, procalcitonin, and soluble CD14. Renal Replacement Therapy. 2017;3:31.

22. Imagawa A, Uozumi E, Shiota Y, Shiraishi R, Ikezawa A, Morita S. Presepsin level in renal dysfunction and hemodialysis patients. Med Technol. 2015; 64(2):169-72.

23. Ramirez-Alejo N, Santos-Argumedo L. Innate defects of the IL-12/IFN- $\gamma$ axis in susceptibility to infections by mycobacteria and salmonella. J Interferon Cytokine Res. 2014;34(5):307-17.

24. Burgess LJ, Reuter H, Carstens ME, Taljaard JJF, Doubell AF. The use of adenosine deaminase and interferon-yas diagnostic tools for tuberculous pericarditis. Chest. 2002;122(3):900-5.

\section{Publisher's Note}

Springer Nature remains neutral with regard to jurisdictional claims in published maps and institutional affiliations. 